\title{
INDEKS PENILAIAN PETANI PADA HUTAN RAKYAT DI KECAMATAN JABIREN RAYA KALIMANTAN TENGAH
}

\author{
(Index Forest Farmer People's Judgment In District Jabiren Raya Of Central Kalimantan)
}

\section{ISE AFITAH}

\author{
Program Studi Kehutanan Fakultas Pertanian dan Kehutanan \\ Universitas Muhammadiyah Palangkaraya \\ JI. RTA Milono Km. 1,5 Palangka Raya, Kalimantan Tengah. 73111
}

e-mail : afitah78@yahoo.com

\begin{abstract}
This study aims to conduct quantitative assessment of farmers' performance in building community forests in terms of physical aspects of the plant (appearance) on the land in community forestry programs and assessing the socio-economic aspects of farmers (in this case the increase of farmer's resources, Acceptance of development funds for community forests and labor).

This research was conducted in 2 (two) villages, namely Jabiren village and Garung village. Both villages are in Jabiren Raya District, Pulang Pisau Regency, Central Kalimantan Province. The time required in the implementation of this research is effectively carried out for 4 (four) months is from March to June 2017.

The general assessment of the farmer's performance success on the physical aspects of the plant is the failing classification (the result of poor judgment). In Jabiren village there are 12 farmers categorized as failing from 20 existing farmers (60\%) while in Garung village there are 10 farmers fall into the failed category of 15 existing farmers (66.7\%).

Distribution, distribution and employment in general assist household farmers in forest community programs in general research in both locations are classified (good assessment results). The value of success of socio-economic aspects of high classification in Jabiren village is 9 farmers from 20 farmers (45\%) and Garung has 7 farmers from 15 farmers (46.7\%). The success of the land part generally leads to the gardens even though the average land area is $\leq 2$ ha and there are plant crops intercropping (can be for sale) so that more people conserve the forest plant.
\end{abstract}

Key word :

\section{ABSTRAK}

Penelitian ini bertujuan untuk melakukan penilaian secara kuantitatif terhadap keberhasilan kinerja petani dalam membangun hutan rakyat ditinjau dari aspek fisik tanaman (penampakan) di lahan dalam program kegiatan hutan rakyat serta melakukan penilaian ditinjau dari aspek sosial ekonomi petani (dalam hal ini adalah peningkatan sumber daya petani, penerimaan dana pembangunan hutan rakyat dan tenaga kerja).

Penelitian ini dilaksanakan di 2 (dua) desa, yaitu desa Jabiren dan desa Garung. Kedua desa tersebut masuk wilayah Kecamatan Jabiren Raya, Kabupaten Pulang Pisau Provinsi Kalimantan Tengah. Waktu yang dibutuhkan dalam pelaksanaan penelitian ini secara efektif dilaksanakan selama 4 (empat) bulan yaitu pada bulan Maret sampai bulan Juni 2017.

Penilaian umum keberhasilan kinerja petani terhadap aspek fisik tanaman adalah pada klasifikasi gagal (hasil penilaian yang buruk). Di desa Jabien ada 12 petani berkategori gagal dari 20 petani yang ada (60\%) sedangkan di desa Garung ada 10 petani masuk dalam kategori gagal dari 15 petani yang ada $(66,7 \%)$.

Penyebaran, pendistribusian dan penyerapan tenaga kerja secara umum membantu petani keluarga dalam program masyarakat hutan pada penelitian umum di kedua lokasi tersebut berklasifikasi (hasil penilaian yang baik). Nilai keberhasilan aspek sosial Ekonomi pada klasifikasi tinggi di desa Jabiren ada 9 petani dari 20 petani (45\%) dan di Garung ada 7 petani dari 15 petani $(46,7 \%)$. Keberhasilan bagian lahan pada umumnya menyebabkan kebun meskipun rata-rata luas lahan $\leq 2$ ha dan telah ada tanaman tumpangsari tanaman (bisa untuk dijual) sehingga lebih banyak orang melestarikan tanaman hutan.

Kata Kunci : Kinerja Petani dan Hutan Rakyat 


\section{PENDAHULUAN}

Pentingnya hutan dengan segala sumberdaya alam yang ada didalamnya dalam rangka mengurangi efek perubahan iklim dan peran penting lainya dalam sistem kehidupan, dan karena kehancuran hutan akan menimbulkan emisi lebih banyak, jelas bahwa kita perlu memperlambat deforestasi dan degradasi hutan dan memelihara kesehatan sistem hutan yang telah tumbuh lama. Ini menimbulkan ide untuk mengurangi emisi dari deforestasi dan degradasi hutan, yaitu ide yang berupaya menghentikan penebangan atau pengerusakan hutan.

Pemerintah menawarkan kegiatan penghijauan melalui pembangunan hutan rakyat yang didasarkan pada inisiatif masyarakat yang mengutamakan masyarakat sebagai pihak perencana, pengambil keputusan dan pengelola, sementara pemerintah lebih berperan sebagai fasilitator untuk mendampingi dan mengarahkan agar dapat menghasilkan manfaat yang berkelanjutan, kebersamaan dan keterpaduan serta yang terpenting memiliki nilai finansial yang maksimum bagi masyarakat luas.

Hutan rakyat mempunyai keunggulan dalam berbagai hal. Pertama, hutan rakyat dapat mendukung perekonomian pedesaan dan dapat dijadikan sebagai katup penyelamat ekonomi masyarakat pada saat krisis sekalipun, hal ini didukung oleh pola agroforestry yang memungkinkan adanya bermacam hasil selain kayu, hutan rakyat juga dimaknai sebagai bentuk tabungan selain ternak. Kedua, walaupun pada awalnya berupa program pemerintah, pengembangan hutan rakyat dipengaruhi oleh kesungguhan masyarakat untuk merehabilitasi lingkungan dan lahan pertanian miliknya, terbangunnya pasar kayu rakyat juga menjadi insentif yang penting yang mendorong masyarakat untuk tetap melestarikan hutan rakyat. Ketiga, hutan rakyat merupakan solusi bagi permasalahan lingkungan.

Penelitian ini bertujuan untuk:

1. Melakukan penilaian secara kuantitatif terhadap keberhasilan kinerja petani dalam membangun hutan rakyat ditinjau dari aspek fisik tanaman (penampakan) di lahan dalam program kegiatan hutan rakyat

2. Melakukan penilaian ditinjau dari aspek sosial ekonomi petani (dalam hal ini adalah peningkatan sumber daya petani, penerimaan dana pembangunan hutan rakyat dan tenaga kerja).

\section{METODOLOGI}

\section{Lokasi dan Waktu Penelitian}

Penelitian ini dilaksanakan di 2 (dua) desa, yaitu desa Jabiren dan desa Garung. Kedua desa tersebut masuk wilayah Kecamatan Jabiren Raya, Kabupaten Pulang Pisau Provinsi Kalimantan Tengah.

$$
\text { Waktu yang dibutuhkan dalam }
$$
pelaksanaan penelitian ini secara efektif dilaksanakan selama 4 (empat) bulan yaitu pada bulan Maret sampai bulan Juni 2017.

\section{Bahan, Peralatan, dan Objek Penelitian}

Bahan dan alat penelitian yang digunakan adalah: tali nilon, digunakan untuk pembuatan petak ukur; microcliper, digunakan untuk mengukur diameter pohon dan tongkat dengan ukuran 6 meter digunakan untuk mengukur tinggi pohon; kamera dan film, 
digunakan untuk mendokumentasikan objek-objek penting yang terkait dalam penelitian ini; peta dan dokumen, digunakan sebagai sumber informasi pendukung; serta alat dan bahan tulis menulis.

Adapun objek pada penelitian ini adalah tanaman pokok yang di tanam pada kegiatan hutan rakyat.

\section{Teknik Pengumpulan Data}

Data penelitian diperoleh dengan menggunakan teknik pengumpulan data sebagai berikut;

1. Observasi; merupakan kegiatan pengamatan dan pengukuran langsung dilapangan. Pengukuran tanaman pokok (tanaman tahunan) dilakukan dengan pembuatan plot berbentuk lingkaran dengan jari-jari 17,8 $\mathrm{m}$. Plot dibuat sebanyak 2 (dua) plot pada lahan yang memiliki luasan $\geq 1$ hektar. Penempatan plot ditentukan sedemikian rupa (diusahakan berada di bagian tengah dari luasan lahan garapan) sehingga dapat mewakili kondisi luasan lahan tersebut. Adapun pengukuran tanaman meliputi: kesehatan tanaman; tinggi tanaman; diameter tanaman; jumlah tanaman perhektar; persen hidup tanaman; dan luasan penutupan lahan hutan rakyat oleh belukar/ilalang.

2. Wawancara; pengumpulan data dilakukan dengan mengajukan pertanyaan tertulis kepada responden menggunakan kuesioner yang telah disiapkan.

3. Studi Dokumentasi; pengumpulan data dilakukan untuk memperoleh data tertulis melalui buku, gambar, foto ataupun sejenisnya guna mendukung data-data yang diperoleh melalui observasi dan kuesioner.

\section{Data Analisis}

Untuk masing-masing analisis yang menggunakan penilaian skala akan dilakukan perhitungan dengan cara berikut (Hadi, 1997):

1) Menentukan rentang nilai dengan rumus Rentang $=$ Nilai Tertinggi - Nilai terendah

2) Menentukan jumlah interval. Jumlah interval ditentukan sesuai dengan kategori/batasan penilaian.

3) Menentukan panjang interval dengan rumus sebagai berikut;

$$
\mathrm{i}=\frac{\mathrm{R}}{\mathrm{K}}
$$

Keterangan :

$\mathrm{i}=$ lebar interval

$\mathrm{R}=$ rentang pengukuran

$\mathrm{K}=$ jumlah interval

\section{Analisis Penilaian Aspek Fisik Tanaman}

Indikator yang digunakan untuk penilaian keberhasilan kinerja petani adalah penampakan dari fisik tanaman, yaitu berupa;

1) Persen hidup tanaman

Perhitungan persen hidup tanaman dengan menggunakan rumus berikut:

$$
\mathrm{Pi}=\frac{n i}{n} \times 100 \%
$$

Di mana;

$\mathrm{Pi}=$ Persen tumbuh tanaman

$\mathrm{ni}=$ Jumlah tanaman hidup di lapangan hasil sensus

$\mathrm{n}=$ Jumlah tanaman yang seharusnya ada (sesuai jarak tanam)

Untuk penilaian pembobotan persen hidup diberi bobot sebesar 40 dan diklasifikasikan dalam 3 (tiga) penilaian dengan skoring sebagai berikut :

1. Persen hidup tanaman pokok $<55 \%=$ gagal 
2. Persen hidup tanaman pokok $55-76 \%=$ cukup berhasil

3. Persen hidup tanaman pokok $>76$ $100 \%$ = berhasil

2) Kualitas tanaman hutan rakyat

Nilai kualitas tanaman hutan rakyat akan diperoleh dari hasil penilaian terhadap variabel kesehatan, diameter dan tinggi tanaman. Adapun skor dan bobot nilai dari masing-masing parameter yang diamati ditujukan Tabel 1 . Penilaian tinggi rendahnya kualitas tanaman didasarkan pada skor indikator penilaiannya dengan model matematis dengan rumus berikut;

$$
K \mathrm{t}=(\mathrm{kst} \times 40)+(\mathrm{t} \times 30)+(\mathrm{d} \times 30)
$$

\section{Dimana;}

$\mathrm{Kt}=$ Nilai kualitas tanaman yang diperoleh berdasarkan bobot dan skor nilai setiap variabel

kst $=$ Nilai skor kesehatan tanaman berdasarkan kondisi tanaman dilihat dari intensitas serangan (hama dan/penyakit)

$\mathrm{t}=$ Nilai skor dari tinggi tanaman

$\mathrm{d}=$ Nilai skor dari diameter tanaman

Berdasarkan rumus di atas akan diperoleh nilai kualitas tanaman maksimum 300 dan diklasifikasikan dalam 3 (tiga) penilaian dengan skoring berikut :

Skor 1. Nilai $-<167=$ kualitas tanaman hutan rakyat rendah.

Skor 2. Nilai $167-233$ = kualitas tanaman hutan rakyat cukup baik.

Skor 3. Nilai $>233-300=$ kualitas tanaman hutan rakyat baik.

3) Persentase luasan penutupan lahan hutan rakyat oleh belukar/ilalang.

Penilaian terhadap penutupan lahan oleh belukar/ilalang diberi bobot 30 dan diklasifikasikan dalam 3 (tiga) penilaian dengan skoring sebagai berikut :
Skor 1. $>66 \%$ luasan lahan ditumbuhi tanaman tidak bermanfaat (belukar/ilalang).

Skor 2. $34-66 \%$ luasan lahan ditumbuhi tanaman tidak bermanfaat (belukar/ilalang).

Skor 3. $<34 \%$ luasan lahan ditumbuhi tanaman tidak bermanfaat (belukar/ilalang).

Berdasarkan perhitungan dari 3 (tiga) peubah diatas akan diperoleh nilai fisik tanaman maksimum 300 yang diperoleh dari penjumlahan hasil perkalian antara skor dengan bobot yang diberikan dengan model matematis berikut;

$$
\mathrm{NFt}=(\mathrm{PH} \times 40)+(\mathrm{Kt} \times 30)+(\mathrm{Ppl} \times 30)
$$

Dimana;

$\mathrm{NFt}=$ Nilai aspek fisik tanaman

$\mathrm{PH}=$ Nilai skor persen hidup tanaman

$\mathrm{Kt}=$ Nilai skor kualitas tanaman hutan rakyat

$\mathrm{Ppl}=$ Nilai skor persentase luasan penutupan lahan oleh belukar/ilalang.

Berdasarkan nilai aspek fisik tanaman yang diperoleh akan diklasifikasikan ke dalam 3 (tiga) penilaian, yaitu;

1. Nilai $>233-300$ : Keberhasilan aspek fisik tanaman tinggi $(\mathrm{A})$.

2. Nilai $167-233$ : Keberhasilan aspek fisik tanaman sedang (B).

3. Nilai -167 : Keberhasilan aspek fisik tanaman rendah $(\mathrm{C})$.

\section{Analisis Penilaian Aspek Sosial Ekonomi} Petani

Indikator keberhasilan kinerja petani dari aspek sosial ekonomi adalah keterlibatan petani dalam kegiatan hutan rakyat.

1) Peningkatan sumberdaya manusia (SDM petani). 
Kegiatan peningkatan SDM petani diberi bobot 30 dan diklasifikasikan dalam 3 (tiga) penilaian dengan skoring sebagai berikut :

\section{Skor 1. Tidak tahu adanya penyuluhan/sosialisasi kegiatan hutan rakyat.}

Skor 2. Dilaksanakan dan tidak mengikuti kegiatan penyuluhan/sosialisasi kegiatan hutan rakyat.

Skor 3. Mengikuti kegiatan penyuluhan/sosialisasi kegiatan hutan rakyat.

2) Bantuan dana pembangunan hutan rakyat.

Bantuan cuma-cuma memotivasi petani dalam pembangunan hutan rakyat, karena itu diberi bobot 40 dan diklasifikasikan dalam 3 (tiga) penilaian dengan skoring sebagai berikut :

Skor 1. Mendapatkan bantuan bibit tanaman pokok dari proyek hutan rakyat.

Skor 2. Mendapatkan sebagian bantuan (bibit tanaman pokok dan tumpangsari, pupuk , racun hama/penyakit, alat pertanian dan dana pemeliharaan) dari proyek hutan rakyat.

Skor 3. Mendapatkan bantuan secara penuh dari proyek hutan rakyat.

3) Jumlah angkatan kerja dalam keluarga yang terserap dalam kegiatan hutan rakyat.

Keberhasilan kegiatan pembangunan hutan rakyat pada tingkat penyerapan tenaga kerja (tenaga kerja keluarga petani/peserta) diberikan bobot 30 dan diklasifikasikan dalam 3 (tiga) penilaian dengan skoring sebagai berikut :
Skor 1. Penyerapan tenaga kerja dari keluarga petani sebanyak 1 (satu) orang.

Skor 2. Penyerapan tenaga kerja dari keluarga petani sebanyak 2 (dua) orang.

Skor 3. Penyerapan tenaga kerja dari keluarga petani lebih dari 2 (dua) orang.

Berdasarkan perhitungan dari 3 (tiga) peubah diperoleh nilai keberhasilan kinerja petani berdasarkan aspek sosial ekonomi petani dengan nilai maksimum 300 yang diperoleh dari penjumlahan hasil perkalian antara skor dengan bobot yang diberikan dengan model matematis berikut;

$\mathrm{NSe}=(p s d m \times 30)+($ bdhr $\times 40)+($ ptk $\times 30)$

Dimana;

$\mathrm{NSe}=$ Nilai aspek sosial ekonomi

psdm = Nilai skor peningkatan sumberdaya manusia

$\mathrm{Kt}=$ Nilai skor dana pembangunan hutan rakyat

$\mathrm{Ppl}=$ Nilai skor penyerapan tenaga kerja

Berdasarkan nilai aspek sosial ekonomi yang diperoleh selanjutnya diklasifikasikan ke dalam 3 (tiga) penilaian, yaitu;

1. Nilai $>233-300:$ Keberhasilan aspek sosial ekonomi tinggi $(A)$.

2. Nilai $167-233$ : Keberhasilan aspek sosial ekonomi sedang (B).

3. Nilai -167 : Keberhasilan aspek sosial ekonomi rendah (C). 


\section{HASIL DAN PEMBAHASAN}

\section{Penilaian Keberhasilan Kinerja Petani dari Aspek Fisik Tanaman}

Secara administratif Kecamatan Jabiren Raya termasuk dalam Pemerintahan Kabupaten Pulang Pisau. Provinsi Kalimantan Tengah. Jumlah Penduduk di Kecamatan Jabiren Raya berjumlah 8.099 jiwa, dengan Luas wilayah 1.323 $\mathrm{Km}^{2}$ dan terdapat delapan (8) desa yang terdiri dari desa Garung, Henda, Simpur, Sakakajang, Jabiren, Pilang, Tumbang Nusa, dan Tanjung Taruna, dengan batas-batas wilayah: Sebelah Utara Kecamatan Kahayan Tengah \& Kabupaten Kapuas, Sebelah Selatan Kecamatan Hilir, Sebelah Barat Kecamatan Sebangau Kuala \& Kota Palangka Raya, Sebelah Timur Kabupaten Kapuas

(https://jv.wikipedia.org/wiki/Jabiren Raya, Pulan g Pisau).

Keberhasilan hutan rakyat erat kaitannya dengan penampakan fisik (adanya tanaman) di areal hutan rakyat. Sasaran utama program hutan rakyat adalah lahan kritis yang dibebani hak milik untuk meningkatkan produktivitas lahan tersebut. Lahan yang produktif artinya tidak saja menghasilkan secara ekonomi, tetapi penting akan tersedianya kondisi tanah yang memungkinkan tumbuhnya berbagai macam tumbuhan (penampakan dari kerapatan tegakan penyusun hutan). Keberadaan vegetasi (tanaman hutan dan tumbuhan lainnya) memiliki fungsi untuk melindungi tanah dari kemungkinan terjadinya erosi tanah baik yang disebabkan oleh air (air hujan dan aliran air) maupun yang disebabkan oleh angin (Awang dkk., 2001). Berdasarkan hal tersebut maka penilaian keberhasilan kinerja petani dilihat dari hasil yang berupa tanaman. Aspek fisik tanaman sebagai indikator keberhasilan dari kinerja petani ditentukan oleh tiga variabel, yaitu persen hidup tanaman, kualitas tanaman dan luasan penutupan lahan hutan rakyat oleh belukar/ilalang.

Persentase penilaian pada persen hidup tanaman yang dicapai ke dua lokasi penelitian tampak pada Tabel 2.

Pada Tabel 2 tersebut ditunjukkan bahwa persen hidup tanaman di dua lokasi penelitian umumnya gagal. Di Jabiren secara keseluruhan keberhasilan petani dalam klasifikasi gagal, yakni 12 petani dalam kategori gagal dari 20 petani yang ada (60 \%). Tidak jauh beda dengan di Desa Garung persentase penilaian persen hidup tanaman umumnya gagal yakni 10 petani masuk dalam kategori gagal dari 15 petani yang ada $(66,7 \%)$

Secara umum penyebab kegagalan antara lain; penanaman pada luasan areal lebih dari 1 ha menyebabkan responden tidak sanggup untuk melakukan pemeliharaan seluruh tanaman, sedangkan tanaman penghijauan untuk sementara tidak dapat memberikan hasil untuk memenuhi kebutuhan sehari-hari, serta akses yang mudah untuk mencari sumber pendapatan lain dimanfaatkan oleh sebagian petani untuk bekerja di luar (sebagian sebagai buruh bangunan) yang mengharuskan meninggalkan pertanian dengan alasan tanaman hutan rakyat tidak memberikan pendapatan untuk memenuhi kebutuhan pokok sehari-hari. 


\section{Penilaian Keberhasilan Kinerja Petani Berdasarkan Keterlibatan dalam Kegiatan Hutan Rakyat Ditinjau dari Aspek Sosial Ekonomi}

Berdasarkan pengamatan di lapangan bahwa keberhasilan berdasarkan keterlibatan petani dalam kegiatan hutan rakyat ditinjau pada aspek sosial ekonomi sesungguhnya sangat penting dalam pengembangan masyarakat, dimana dengan peningkatan kondisi sosial ekonomi (kontribusi yang diberikan dari kegiatan hutan rakyat) akan memberikan motivasi dalam pengelolaan dan pengembangan hutan rakyat ke depan. Adapun persentase tingkat keberhasilannya tampak pada Tabel 3.

Tabel 1. Parameter, Bobot dan Skor Kualitas Tanaman

\begin{tabular}{|c|c|c|}
\hline Peubah & Bobot & Skor \\
\hline 1. Kesehatan tanaman & 40 & $\begin{array}{l}\text { 1. Rendah (tanaman rusak sedang-berat) } \\
\text { 2. Sedang (tanaman rusak ringan) } \\
\text { 3. Tinggi (tanaman sehat) }\end{array}$ \\
\hline 2. Tinggi tanaman & 30 & $\begin{array}{l}\text { 1. Rendah ( } 0-33 \% \text { dari rentang nilai rataan } \\
\text { tinggi pohon keseluruhan) } \\
\text { 2. Sedang ( } 34-66 \% \text { dari rentang nilai rataan } \\
\text { tinggi pohon keseluruhan) } \\
\text { 3. Tinggi ( } 67-100 \% \text { dari rentang nilai rataan } \\
\text { tinggi pohon keseluruhan) }\end{array}$ \\
\hline 3. Diameter tanaman & 30 & $\begin{array}{l}\text { 1. Rendah ( } 0-33 \% \text { dari rentang nilai rataan } \\
\text { diameter pohon keseluruhan) } \\
\text { 2. Sedang ( } 34-66 \% \text { dari rentang nilai rataan } \\
\text { diameter pohon keseluruhan) } \\
\text { 3. Tinggi }(67-100 \% \text { dari rentang nilai rataan } \\
\text { Diameter pohon keseluruhan) }\end{array}$ \\
\hline
\end{tabular}

Tabel 2. Persentase Penilaian Persen Hidup Tanaman Pada Kegiatan Hutan Rakyat

\begin{tabular}{cccccc}
\hline Desa & $\begin{array}{c}\text { Penilaian } \\
\text { Persen Hidup }\end{array}$ & $\begin{array}{c}\text { Klasifikasi } \\
\text { Penilaian }\end{array}$ & Skor & $\begin{array}{c}\text { Jumlah } \\
\text { (petani) }\end{array}$ & $\begin{array}{c}\text { Persentase } \\
(\%)\end{array}$ \\
\hline Jabiren & $<55 \%$ & Gagal & 1 & 12 & 60 \\
& $55 \%-76 \%$ & Sedang & 2 & 8 & 40 \\
\hline Garung & $>76 \%-100 \%$ & Tinggi & 3 & & \\
& $>0 \%-<55 \%$ & Gagal & 1 & 10 & 66,7 \\
& $55 \%-76 \%$ & Sedang & 2 & 5 & 33,3 \\
\hline
\end{tabular}


Tabel 3. Persentase Penilaian Keberhasilan Kinerja Petani dalam Pembangunan Hutan Rakyat Ditinjau dari Aspek Sosial Ekonomi Petani

\begin{tabular}{lccccc}
\hline Desa & Tingkat Penilaian & $\begin{array}{c}\text { Klasifikasi } \\
\text { Penilaian }\end{array}$ & Skor & $\begin{array}{c}\text { Jumlah } \\
\text { (petani) }\end{array}$ & $\begin{array}{c}\text { Persentase } \\
(\%)\end{array}$ \\
\hline Jabiren & $-<167$ & Rendah @ & 1 & 8 & 40 \\
& $167-233$ & Sedang (B) & 2 & 9 & 45 \\
Garung & $>233-300$ & Tinggi (A) & 3 & 3 & 15 \\
& $-<167$ & Rendah ( $)$ & 1 & 6 & 40 \\
& $167-233$ & Sedang (B) & 2 & 7 & 46,7 \\
& $>233-300$ & Tinggi (A) & 3 & 2 & 13,3 \\
\hline
\end{tabular}

\section{KESIMPULAN DAN SARAN}

\section{Kesimpulan}

Berdasarkan hasil 185ela had data dan pembahasan maka dapat ditarik beberapa kesimpulan, antara lain:

1. Secara umum penilaian keberhasilan kinerja petani pada aspek fisik tanaman berada pada klasifikasi gagal (hasil penilaian buruk). Di Desa Jabiren terdapat 12 petani masuk dalam kategori gagal dari 20 petani yang ada (60\%), di Desa Garung terdapat 10 petani masuk dalam kategori gagal dari 15 petani yang ada (66,7 \%).

2. Kegiatan penyuluhan/ sosialisasi, distribusi bantuan dan penyerapan tenaga kerja keluarga petani dari program hutan rakyat secara umum di dua lokasi penelitian berklasifikasi sedang (hasil penilaian baik). Nilai keberhasilan aspek sosial ekonomi pada klasifikasi tinggi di Desa Jabiren terdapat 9 petani dari 20 petani $(45 \%)$ dan di Garung terdapat 7 petani dari 15 petani $(46,7 \%)$.

3. Secara umum penilaian keberhasilan petani pada dua aspek penilaian umumnya baik, hal ini disebabkan sebagian lahan berupa tanaman kebun walaupun luasan lahan rata-rata $\leq 2$ ha dan telah ada tanaman
4. tumpangsari yang menghasilkan (bisa dijual) sehingga tanaman hutan rakyat lebih terpelihara.

5. Belum maksimalnya keberhasilan yang dicapai disebabkan oleh beberapa faktor antara lain, yaitu pola pemanfaatan lahan oleh petani lebih dititik beratkan pada hasil pertanian yang lebih cepat mendatangkan keuntungan, sehingga waktu, biaya dan tenaga yang ada lebih banyak digunakan untuk kegiatan usaha pertanian serta banyak bibit dari proyek tidak ditanam karena kurangnya tenaga yang tersedia yang umumnya lahan untuk hutan rakyat cukup luas (lebih dari 1 hektar).

\section{Saran}

Penilaian keberhasilan hutan rakyat ditinjau dari aspek fisik tanaman dan sosial ekonomi petani dinilai dapat mewakili untuk pencapaian tujuan pembangunan hutan rakyat. Karena itu sebaiknya pihak-pihak terkait bekerja keras untuk terus melakukan yang terbaik bagi masyarakat dan alam lingkungan sekitar sehingga keberhasilan rehabilitasi hutan dan lahan dapat tercapai dengan baik di masa yang akan datang. 


\section{DAFTAR PUSTAKA}

Awang, S., Santosa, H., Widayanti, W. T., Nugroho, Y., Kustomo, Sapardiono, 2001. Gurat Hutan Rakyat Di Kapur Selatan. Debut, Yogyakarta.

BPS Kota Palangkaraya, 2004. Pulang Pisau Dalam Angka 2004. Badan Pusat Statistik (BPS) Kota Palangkaraya. Palangkaraya.

Hadi, S., 1997. Statistik Jilid 1. Penerbit Andi, Yogyakarta.

Pemkab. Pulang Pisau. Garung, Jabiren Raya, Pulang Pisau. https://jv.wikipedia.org/wiki/Jabiren Ra ya, Pulang Pisau diakses tanggal 21 Juli 2017, jam 12.00wib. 